\title{
DIFFERENCES EFFECT OF PROGRESSIVE MUSCLE RELAXATION THERAPY AND SUPPORTIVE THERAPY ON PARENTS ANXIETY WITH CHILDREN HOSPITALIZATION AT RSUD.DR.R.SOEDJONO SELONG EAST LOMBOK
}

\author{
Farida Maemunah Martiningsih', Retty Ratnawaty', Asti Melani Astari ${ }^{3}$ \\ ${ }^{1}$ Dinas Kesehatan Lombok Timur \\ ${ }^{23}$ Master of Nursing Program, Faculty of Medicine Universitas Brawijaya
}

\begin{abstract}
Hospitalization is an issue that is not expected by everyone, especially children, because they have to undergo some procedure of action and examination. This problem causes anxiety and stress for parents, one of which is marked by muscle tension. This problem can be overcome by nursing actions using Progressive Muscle Relaxation Therapy and Supportive Therapy. The study aims to distinguish the influence of Progressive Muscle Relaxation Therapy and Supportive Therapy in reducing the anxiety parents with children undergoing hospitalization. The research applied quantitative approach with Quasi experimental pre post test, the number of respondents 25 pairs of parent each group, using purposive sampling technique. The research location at RSUD.Dr.R.Soedjono Selong, East Lombok regency on August to October 2017. Based on the result of the study showed decrease of anxiety score the Progressive Muscle Relaxation Therapy was lower than Supportive Therapy, which was $6.30<10.44$, and $t$ value was 0.000 . The used of Progressive Muscle Relaxation Therapy was significant which $p$ value was 0.000 . The conclusion of the study results There was a difference in effect between Progressive Muscle Relaxation Therapy and Supportive Therapy in lowering parental anxiety levels, with the results of Progressive Muscle Relaxation Therapy is better to lower parental anxiety than Suportive Therapy. Further research needs to be developed modification of Progressive Muscle Relaxation Therapy versus Supportive Therapy in other groups.
\end{abstract}

Keywords: Hospitalized, Anxiety, Progressive Muscle Relaxation Therapy and Supportive Therapy

\begin{abstract}
ABSTRAK
Hospitalisasi merupakan masalah yang tidak diharapkan semua orang terutama anak-anak karena harus menjalani beberapa prosedur tindakan dan pemeriksaan. Masalah ini menyebabkan rasa cemas dan stres bagi orangtua, salah satunya ditandai adanya ketegangan otot. Masalah ini dapat diatasi dengan tindakan keperawatan menggunakan Terapi Relaksasi Otot Progresif dan Terapi Suportif. Tujuan penelitian ini adalah menganalisis perbedaan pengaruh Terapi Relaksasi Otot Progresif dan Terapi Suportif dalam menurunkan kecemasan orang tua dengan anak yang menjalani hospitalisasi. Pendekatan penelitian ini kuantitatif dengan metode Quasi experimental pre post test, menggunakan teknik purposive sampling, responden 25 pasang orangtua setiap kelompok. Lokasi penelitian di RSUD. Dr. R. Soedjono Selong Kabupaten Lombok Timur dilaksanakan bulan Agustus - Oktober 2017. Berdasarkan hasil penelitian menunjukkan penurunan skor kecemasan pada Terapi Relaksasi Otot Progresif lebih rendah $(6,30)$ dari Terapi Suportif $(10,44)$ dengan nilai $p$ uji $t=0,000$. Kesimpulan hasil penelitian adalah terdapat perbedaan pengaruh antara Terapi Relaksasi Otot Progresif dan Terapi Suportif dalam menurunkan tingkat kecemasan orangtua, dengan hasil Terapi Relaksasi Otot Progresif lebih baik menurunkan kecemasan orangtua dibandingkan Terapi Suportif Penelitian selanjutnya perlu dikembangkan modifikasi Terapi Relaksasi Otot Progresif dibandingkan Terapi Suportif pada kelompok lain.
\end{abstract}

Kata Kunci: Hospitalisasi, Cemas, Terapi Relaksasi Otot Progresif dan Terapi Suportif

Jurnal IImu Keperawatan, Vol. 6, No.1 Mei 2018; Korespondensi : Farida Maemunah. Dinas Kesehatan Lombok Timur. Email : herfa.mm82@gmail.com 


\section{PENDAHULUAN}

Hospitalisasi adalah suatu proses yang disebabkan alasan tertentu baik keadaan darurat atau berencana dan meng-haruskan anak untuk tinggal di Rumah Sakit untuk menjalani terapi serta perawatan sam-pai pemulangan kembali ke rumah (Suryanti, 2013). Hasil survey UNICEF tahun 2012 menyatakan $84 \%$ anak menjalani hospitalisasi sedangkan data WHO pada tahun 2011 menunjukkan jumlah anak yang menjalani hospitalisasi sebanyak 152 juta anak (Kavin,D, 2011). Di Indonesia setiap tahunnya terdapat lebih dari 5.000.000 anak yang menjalani perawatan di RS (Cherty \& Kozak, 2001; Kurniawati, Id, 2011), dimana masalah anak dengan hospitalisasi akan memberikan respon kecemasan terhadap orangtua maupun keluarga.

Kecemasan merupakan kekhawatiran yang tidak jelas dan menyebar, berkaitan dengan perasaan tidak pasti dan tidak berdaya. Keadaan emosi ini tidak memiliki obyek yang jelas, dialami secara subyektif dan dikomunikasikan secara interpersonal (Stuart,2013). Menurut Sadock \& Sadock (2010) beberapa faktor yang mempengaruhi kecemasan seseorang yaitu faktor intrinsik meliputi usia, pengalaman menjalani pengobatan, konsep diri dan peran, sedangkan faktor ekstrinsik meliputi kondisi medis, tingkat pendidikan, akses informasi, proses adaptasi, dan tingkat sosial ekonomi.

\section{Penelitian oleh Audina (2017)} menyatakan ada hubungan antara dampak hospitalisasi anak dengan lamanya rawat inap, diagnose penyakit anak, dan tingkat pendidikan orangtua terhadap kecemasan orang tua dengan presentase terbanyak adalah kecemasan berat.
Salah satu tanda seseorang mengalami stress adalah adanya ketegangan otot dan kecemasan merupakan tanda kesiapan tubuh terhadap potensial kejadian yang berbahaya, sehingga individu pada kondisi cemas/ ansietas memerlukan banyak energi untuk mengembalikan ketidak seimbangan yang terjadi akibat respon terhadap kecemasan yang dialami (Center for clinical intervention, 2008). Kondisi ketenangan psikologis sangat diperlukan orangtua dan keluarganya agar dapat mendukung proses perawatan sehingga kesembuhan anak dapat berjalan lebih cepat.

Beberapa upaya yang dapat dilakukan oleh tenaga perawat terhadap orangtua, keluarga, ataupun pasien dalam meminimalkan kecemasan sebagai reaksi stres dari hospitalisasi anak, dapat dilakukan dengan pemberian terapi keperawatan jiwa antara lain Terapi Relaksasi Otot Progresif. Relaksasi otot progresif ini digunakan untuk melawan rasa cemas, stres, atau tegang, selanjutnya menegangkan dan melemaskan beberapa kelompok otot dan membedakan sensasi tegang dan rileks, sehingga seseorang bisa menghilangkan kontraksi otot dan mengalami rasa rileks (Soewondo, 2009).

Penelitian yang dilakukan Sari (2015) menyatakan tentang pe-latihan teknik relaksasi, salah satunya dengan Terapi Relaksasi Otot Progresif terbukti dapat menurunkan kecemasan pada Primary Caregiver penderita kanker payudara. Penelitian yang dilakukan oleh Choi (2010) pada penelitiannya yang berjudul The Effect of Music and Progressive Muscle Relaxation on Anxiety, Fatigue, and Quality of Life in Family Caregivers of Hospice Patients 
mendapatkan hasil bahwa terdapat perbedaan hasil yang signifikan pada kecemasan, kelelahan, dan peningkatan kualitas hidup pada caregivers di sebuah Rumah Sakit keluarga.

Tindakan terapi keperawatan lain yang dapat digunakan untuk menurunkan tingkat kecemasan selain Terapi Relaksasi Otot Progresif adalah menggunakan Terapi Suportif. Menurut Stuart (2007) Terapi Suportif adalah salah satu bentuk terapi kelompok psikoterapi yang berbeda dengan bentuk terapi kelompok lainnya, dimana terapi ini bersifat ekletik yang tidak tergantung terhadap satu konsep atau teori, serta menggunakan psikodinamik untuk memahami perubahan prilaku akibat faktor biopsikososial dengan penekanan pada respon koping maladaptive.

\section{Hasil penelitian Dewi} menunjukkan ada perbedaan beban dan kecemasan keluarga sebelum dan sesudah mendapatkan terapi kelompok Suportif. Penelitian lain yang telah dilakukan oleh Damayanti, R (2010) menjelaskan bahwa setelah dilakukan Terapi Suportif pada keluarga klien yang mengalami gangguan jiwa, menunjukkan hasil yang signifikan pada peningkatan kognitif, psikomotor dalam merawat anggota keluarganya.

Hasil studi pendahuluan yang dilakukan oleh peneliti pada bulan Maret 2017 di Ruang Anak RSUD.Dr. R.Soedjono Selong Kabupaten Lombok Timur, bahwa jumlah anak yang menjalani perawatan selama tahun 2016 adalah sebanyak 2410 anak, dan pada bulan Januari sampai dengan Februari tahun 2017 jumlah anak yang menjalani hospitalisasi sebanyak 478 anak. dimana 70\% orangtua mengalami kecemasan yang disebabkan karena anak menjalani hospitalisasi, dan $30 \%$ kecemasan orang tua karena masalah pembiayaan.

Orangtua pada saat anak menjalani hospitalisasi seringkali mengalami kecemasan akibat stress. Masalah kecemasan pada orangtua apabila tidak mempunyai mekanisme koping yang baik, dapat menjadi kecemasan berat atau panik. Masalah ini dapat menambah stressor bagi anak yang sedang membutuhkan dukungan kedua orangtuanya. Sehingga dalam kondisi ini orangtua sangat membutuhkan dukungan secara emosi dan sosial tidak hanya dari keluarga atau kerabat, tetapi membutuhkan dukungan dari lingkungannya. Dalam melakukan intervensi keperawatan menggunakan psikoterapi, masalah psikososial seperti kecemasan dan depresi ini dapat diatasi dengan menggunakan Terapi Relaksasi Otot Progresif dan Terapi Suportif.

Terapi Relaksasi Otot Progresif ini disebut sebagai bentuk ketrampilan koping aktif, karena terapi ini dapat diterapkan langsung pada situasi yang dapat menimbulkan kecemasan. Diharapkan dengan menggunakan terapi ini masalah yang timbul pada gejala fisik dan psikologis orangtua akibat kecemasan dapat teratasi. Bentuk terapi yang efektif untuk mengatasi masalah kecemasan orangtua yang mempengaruhi respon psikomotor, prilaku, dan sosial adalah dengan menggunakan Terapi Suportif, agar kemampuan koping individu, berkaitan dengan kemampuan problem solving dan mempersepsikan sesuatu, yang berfokus pada aspek 
kognitifnya dapat menjadi lebih baik dalam mengatasi masalah kecemasannya.

Berdasarkan kemampuan dan kelebihan dari masing-masing jenis psikoterapi ini dalam mengatasi masalah psikososial seperti kecemasan, dan berdasarkan keberhasilan penelitian yang telah dilakukan oleh para peneliti sebelumnya tentang keefektifan dari Terapi Relaksasi Otot Progresif dan Terapi Suportif dalam mengatasi masalah kecemasan, maka peneliti ingin menggunakan kedua jenis terapi ini dalam mengatasi masalah kecemasan orangtua di lokasi penelitian. Tujuan umum dari penelitian ini adalah menganalisis perbedaan pengaruh Terapi Relaksasi Otot Progresif dan Terapi Suportif terhadap kecemasan orangtua dengan anak hospitalisasi di RSUD.Dr.R.Soedjono Selong Kabupaten Lombok Timur.

\section{METODE}

Penelitian ini menggunakan desain penelitian "Quasi experimental pre post test" yaitu melakukan observasi sebelum dan sesudah diberikan suatu perlakuan.

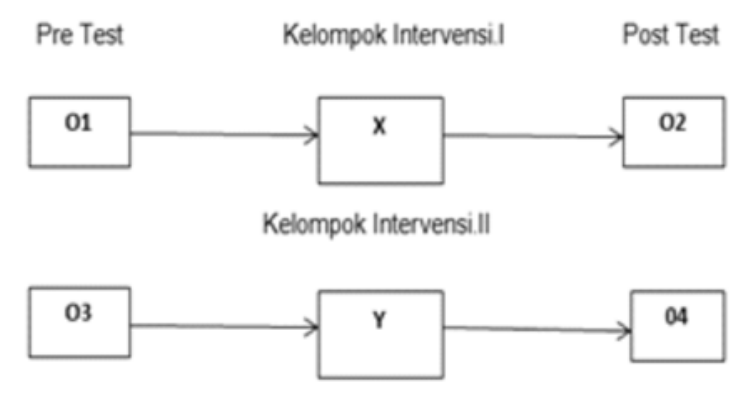

Gambar.4.1. Desain Penelitian

Perbedaan Pengaruh Therapy Progressive Muscle Relaxation dan Therapy Suportif terhadap Tingkat Kecemasan Orangtua dengan Anak Hospitalisasi di RSUD . Dr.R Soedjono Selong Kabupaten Lombok Timur
Penelitian ini dilakukan di ruang anak di RSUD. Dr.R.Soedjono Selong Kabupaten Lombok Timur periode Agustus-Oktober 2017. Dengan teknik pengambilan sampel Purposive Sampling diperoleh 25 pasang orangtua (50 orang tiap kelompok) sebagai responden sesuai kriteria inklusi. Analisa data menggunakan analisis paired $t$ test untuk mengetahui pengaruh skor kecemasan sebelum dan sesudah diberikannya terapi yang sama, dan analisis independent t-test untuk mengetahui perbedaan pengaruh dari kedua terapi, dimana masing-masing variabel harus berdistribusi normal.

Instrumen pada penelitian ini menggunakan kuisoner kecemasan HARS untuk mengetahui skor kecemasan pada orangtua dengan anak yang menjalani hospitalisasi. Kuisioner kecemasan ini sudah dilakukan uji validitas realibilitas di RS berbeda dengan tempat penelitian yaitu di RS. Islam Namira Selong Kabupaten Lombok Timur. Peneliti melakukan pemberian terapi keperawatan lanjut ini setelah memperoleh izin dan mendapatkan lisensi dari perawat spesialis jiwa melalui ujian praktek kemampuan pelaksanaan terapi.

Pemberian terapi pada kelompok intervensi I dengan menggunakan Terapi Relaksasi Otot Progresif, yang terdiri dari 3 sesi yaitu sesi satu mengidentifikasikan ketegangan otot-otot yang di-rasakan, sesi dua adalah pelaksanaan Terapi Relaksasi Otot Progresif, dan sesi tiga melakukan evaluasi. Selanjutnya pemberian terapi pada kelompok intervensi II dengan menggunakan Terapi Suportif yang terdiri dari 4 sesi dalam 2 kali waktu pertemuan (sesi I dan sesi II pada pertemuan satu, sesi III dan sesi IV pada 
pertemuan kedua) masing-masing sesi dilakukan selama 40 sampai 60 menit.

\section{HASIL PENELITIAN}

\section{Tabel 1. Hasil Karakteristik Demografi}

\begin{tabular}{|c|c|}
\hline Karakteristik & Nilai \\
\hline \multicolumn{2}{|l|}{ Usia mean, (min-max) } \\
\hline - Terapi Relaksasi Otot Progresif & $31.3(18-47)$ \\
\hline - Suportif Therapy & $32.12(20-47)$ \\
\hline \multicolumn{2}{|l|}{ Pendidikan n(\%) } \\
\hline \multicolumn{2}{|l|}{ a. SD } \\
\hline - Terapi Relaksasi Otot Progresif & $7(14 \%)$ \\
\hline - Terapi Suportif & $3(6 \%)$ \\
\hline \multicolumn{2}{|l|}{ b. SMP } \\
\hline - Terapi Relaksasi Otot Progresif & $13(26 \%)$ \\
\hline - Terapi Suportif & $14(28 \%)$ \\
\hline \multicolumn{2}{|l|}{ c. SMA } \\
\hline - Terapi Relaksasi Otot Progresif & $20(40 \%)$ \\
\hline - Terapi Suportif & $14(46 \%)$ \\
\hline \multicolumn{2}{|l|}{ d. PT } \\
\hline - Terapi Relaksasi Otot Progresif & $10(20 \%)$ \\
\hline - Terapi Suportif & $10(20 \%)$ \\
\hline \multicolumn{2}{|l|}{ Jenis Pekerjaan } \\
\hline \multicolumn{2}{|l|}{ a. Tidak Bekerja n(\%) } \\
\hline - Terapi Relaksasi Otot Progresif & $17(34 \%)$ \\
\hline - Terapi Suportif & $20(40 \%)$ \\
\hline \multicolumn{2}{|l|}{ b. Pegawai swasta $n(\%)$} \\
\hline - Terapi Relaksasi Otot Progresif & $14(28 \%)$ \\
\hline - Terapi Suportif & $14(28 \%)$ \\
\hline \multicolumn{2}{|l|}{ c. PNS n(\%) } \\
\hline - Terapi Relaksasi Otot Progresif & $2(4 \%)$ \\
\hline - Terapi Suportif & $1(2 \%)$ \\
\hline \multicolumn{2}{|l|}{ d. Lain-Lain n(\%) } \\
\hline - Terapi Relaksasi Otot Progresif & $17(34 \%)$ \\
\hline - Terapi Suportif & $15(30 \%)$ \\
\hline \multicolumn{2}{|l|}{ Lama Rawat n(\%) } \\
\hline \multicolumn{2}{|l|}{ a. $<3$ hari } \\
\hline - Terapi Relaksasi Otot Progresif & $18(36 \%)$ \\
\hline • Terapi Suportif & $15(30 \%)$ \\
\hline \multicolumn{2}{|l|}{ b. > 3 hari } \\
\hline - Terapi Relaksasi Otot Progresif & $32(64 \%)$ \\
\hline - Terapi Suportif & 35 (70\%) \\
\hline
\end{tabular}

Dari Tabel 1 diatas menunjukkan bahwa usia terendah responden pada kelompok
Terapi Relaksasi Otot Progresif adalah 18 tahun, tertinggi 47 tahun dengan rata rata usia 31.30. Sedangkan pada kelompok Terapi Suportif usia terendah 20 tahun, tertinggi 47 tahun dengan rata-rata usia 32.12. Menurut tingkat pendidikan, kelompok Terapi Relaksasi Otot Progresif sebagian besar berpendidikan SMA yaitu sebanyak 20 orang $(40 \%)$, tingkat pendidikan terendah yaitu SD sebanyak 7 orang (14\%), sedangkan kelompok Terapi Suportif sebagian besar responden berpendidikan SMA sebanyak 23 orang (46\%), tingkat pendidikan terendah yaitu SD sebanyak 3 orang (6\%). Menurut jenis pekerjaan sebagian besar status pekerjaan responden kelompok Terapi Relaksasi Otot Progresif sebagai lain-lain dan tidak bekerja (tidak tetap) yaitu masingmasing sebanyak 17 orang (34\%), status pekerjaan terendah yaitu sebagai PNS sebanyak 2 orang (4\%). Sedangkan kelompok Terapi Suportif sebagian besar status pekerjaan responden adalah tidak bekerja (tidak tetap) sebanyak 20 orang $(40 \%)$, dan status pekerjaan terendah adalah sebagai PNS sebanyak 1 orang responden (2.0 \%). Menurut lama rawat kelompok responden yang diberikan Terapi Relaksasi Otot Progresif dengan lama perawatan anak $<3$ hari sebanyak 32 orang $(64 \%)$ dan lama perawatan anak $>3$ hari sebanyak 18 orang (36\%), sedangkan lama perawatan anak kelompok responden yang diberikan Terapi Suportif dengan lama perawatan anak <3 hari sebanyak 35 orang (70\%), sedangkan lama perawatan anak >3 hari sebanyak 15 orang $(30 \%)$.

www.jik.ub.ac.id 


\begin{tabular}{cccc} 
& & Sebelum & Sesudah \\
\hline Terapi Relaksasi Otot & Mean & 20.24 & 6.30 \\
Progresif & Std. Dev & 5.741 & 4.657 \\
& Min & 10 & 0 \\
& Max & 33 & 15 \\
\hline Terapi Suportif & Mean & 20.22 & 10.44 \\
& Std. Dev & 5.323 & 2.697 \\
& Min & 10 & 7 \\
& Max & 39. & 19 \\
\hline
\end{tabular}

Skor rata-rata kecemasan kelompok Terapi Relaksasi Otot Progresif adalah 20.24 dengan standar deviasi 5.741, serta skor minimal kecemasan responden adalah 10 dan skor maksimal adalah 33. Setelah diberikan terapi terdapat perubahan skor rata-rata kecemasan menjadi 6.30, dengan standar deviasi 4.657, serta skor minimal kecemasan responden adalah 0 dan skor maksimal kecemasan responden adalah 15 .
Rata-rata skor kecemasan responden kelompok Terapi Suportif adalah 20.22, standar deviasi 5.323, dengan skor minimum 10 dan skor maksimalnya 39. Setelah diberikan terapi terdapat perubahan skor menjadi rata rata 10.44 , standar deviasi 2.697, dengan skor minimum kecemasan responden adalah 7 dan skor maksimal kecemasan responden 19.

Tabel 3. Hasil Uji Beda Skor Kecemasan Pretest dan Posttest

\begin{tabular}{cccccc}
\hline Terapi & Skor & Rata-Rata & $\%$ & Selisih & Sig Uji t \\
\hline Progresif & Pretest & 20.24 & 68,87 & \multirow{2}{*}{13.94} & 0.000 \\
& Posttest & 6.3 & & & \\
\hline Suportif & Pretest & 20.22 & 48,37 & 9.78 & 0.000 \\
& Posttest & 10.44 & & & \\
\hline
\end{tabular}

Dari tabel.3 diketahui bahwa responden yang diberikan terapi Terapi Relaksasi Otot Progresif mampu menurunkan skor kecemasan dengan selisih 13,94. Selisih tersebut adalah bermakna secara statistik $(\mathrm{sig}=0,000)$. Sedangkan responden yang diberikan Terapi Suportif juga mampu menurunkan skor kecemasan dengan selisih 13,94. Selisih tersebut bermakna secara statistik (sig=0,000). 
Tabel 4. Hasil Uji Bivariat Karakteristik Responden dengan Skor Kecemasan Pretest dan Posttest

\begin{tabular}{|c|c|c|c|c|}
\hline \multirow[t]{2}{*}{ Kakteristik } & \multicolumn{2}{|c|}{ Rata-Rata Kecemasan } & \multicolumn{2}{|c|}{ Rata-Rata Kecemasar } \\
\hline & Pretest & Sig & Posttest & Sig \\
\hline \multicolumn{5}{|l|}{ Jenis Kelamin } \\
\hline$\bullet L$ & 18.34 & \multirow{2}{*}{0.000} & 7.74 & \multirow{2}{*}{0.146} \\
\hline$\bullet P$ & 22.12 & & 9.00 & \\
\hline Usia & - & 0.106 & - & 0.857 \\
\hline \multicolumn{5}{|l|}{ Pendidikan } \\
\hline •SD & 19.80 & \multirow{4}{*}{0.959} & 7.50 & \multirow{4}{*}{0.640} \\
\hline •SMP & 20.52 & & 7.93 & \\
\hline - SMA & 20.37 & & 9.00 & \\
\hline$\bullet$ PT & 19.75 & & 8.05 & \\
\hline \multicolumn{5}{|l|}{ Pekerjaan } \\
\hline - Tidak Bekerja & 21.00 & \multirow{4}{*}{0.735} & 8.73 & \multirow{4}{*}{0.870} \\
\hline - Pegawai Swasta & 19.71 & & 7.93 & \\
\hline - PNS & 18.67 & & 7.33 & \\
\hline -Wiraswasta & 19.94 & & 8.44 & \\
\hline \multicolumn{5}{|l|}{ Lama rawat (hari) } \\
\hline$\bullet<3$ & 20.12 & \multirow{2}{*}{0.776} & 8.46 & \multirow{2}{*}{0.762} \\
\hline$\bullet>3$ & 20.45 & & 8.18 & \\
\hline
\end{tabular}

Dari table 4 diketahui bahwa sebelum intervensi, perbedaan skor kecemasan lakilaki dan perempuan adalah bermakna $(\operatorname{sig}=0,000)$. Setelah intervensi, skor kecemasan laki-laki dan perempuan tidak lagi berbeda $(\operatorname{sig}=0,146)$. Sedangkan karakteristik lain tidak menunjukkan adanya perbedaan baik sebelum maupun sesudah intervensi. Dengan kata lain kedua jenis terapi yaitu Terapi Relaksasi Otot Progresif dan Terapi Suportif memberikan hasil yang baik untuk menurunkan skor kecemasan pada responden laki-laki maupun perempuan.

Koefisien yang diperoleh adalah 4,231 artinya jika responden diberikan terapi tersebut maka akan menurunkan skor kecemasan sebesar 4,231 dibandingkan Terapi Suportif. Hal ini menunjukkan Terapi Relaksasi Otot Progresif memiliki efek yang lebih baik.

\section{PEMBAHASAN}

Pengaruh Terapi Relaksasi Otot Progresif terhadap kecemasan orang tua dengan anak hospitalisasi

Hasil penelitian terdahulu yang telah dilakukan terhadap pemberian Terapi Relaksasi Otot Progresif, beberapa diantaranya dapat menurunkan kecemasan, Insomnia, stress, menurunkan rasa nyeri dan ketegangan otot (Saputri, F.D, 2016; Triwijaya, et al, 2014; Fatimah U, 2013; Saedi,M et al 2012; Tobing D.L, 2012; Uskenat, M.D, 2012; Supriatin,L, 2010; Choi,YK, 2010). Menurut Lee,J.E dkk (2012) bahwa terapi relaksasi otot progresif akan memberikan efek relaksasi yang dapat mengurangi kecemasan, serta meningkatkan status fisik dan psikologis dari pasien, dan Center for clinical intervention (2008) menjelaskan apabila terjadi kecemasan dapat 
menimbulkan beberapa sensasi serta perubahan fisik, meliputi peningkatan aliran darah menuju otot, ketegangan otot, mempercepat atau memperlambat pernapasan, meningkatkan denyut jantung serta menurunkan fungsi digestif.

Kecemasan sebagai akibat dari ketidakmampuan seseorang melakukan adaptasi terhadap situasi kehidupan, sehingga kondisi ini akan melibatkan sistem saraf otonom dalam tubuh, dimana sistem saraf otonom tubuh manusia terdiri dari saraf simpatis dan para-simpatis. Fungsi sistem saraf otonom ini secara tidak sadar akan berespon terhadap kecemasan yang dialami oleh individu yang akan menyebabkan terjadinya perubahan fisiologis seperti perubahan tanda-tanda vital (Seyle, 1956; Videbeck, 2008).

Terapi Relaksasi Otot Progresif merupakan salah satu teknik relaksasi yang dapat digunakan sebagai manajemen stres, dimana kondisi stress seseorang dapat mempengaruhi kecemasannya. Menurut Ramdani \& Putra (2009), relaksasi seringkali digunakan untuk menjelaskan suatu bentuk aktivitas yang menyenangkan, dimana relaksasi dapat menghasilkan sensasi perasaan yang menyenangkan, selain mengurangi ketegangan, terutama ketegangan psikologis dalam kaitannya dengan masalah kehidupan, hal ini sesuai dengan hasil penelitian yang sudah dilakukan peneliti, bahwa pemberian Terapi Relaksasi Otot Progresif dapat menurunkan kece-masan responden secara signifikan dengan dengan penurunan skor kecemasan sebesar $68.87 \%$.
Berdasarkan hasil penelitian yang sudah dilakukan peneliti membuktikan bahwa pemberian Terapi Relaksasi Otot Progresif dapat diberikan terhadap orangtua anak yang menjalani hospitalisasi, dan setelah menjalani terapi maka responden mempunyai kemampuan tentang teknik relaksasi dalam mengatasi kecemasannya, dengan latihan yang dilakukan dapat memperkuat koping adaptif bagi individu.

\section{Pengaruh Terapi Suportif terhadap kecemasan orangtua dengan anak hospitalisasi}

Beberapa penelitian yang telah dilakukan oleh beberapa peneliti sebelumnya telah membuktikan bahwa pemberian Terapi Suportif selain dapat meningkatkan koping keluarga/individu, bahwa Terapi Suportif juga dapat menurunkan kecemasan, stress dan meningkatkan kemampuan seseorang dalam bersosialisasi karena mempunyai strategi koping yang sehat dan adaptif untuk megatasi masalah yang dihadapi (Damayanti, R, 2010; Sari,Hasmila, 2010; Widianti Efri, 2011; Wahyuningsih,S.A, 2011; Dewi Erti,I, 2011; Swasti Keksi,G ,2013; Hidayati,E, 2013).

Pemberian Terapi Suportif terhadap keluarga memiliki beberapa tujuan diantaranya dapat menghindarkan seseorang dari perasaan menarik diri, memberikan dukungan emosional, dan mendorong strategi koping yang sehat dan adaptif untuk menangani kehidupan yang penuh dengan stres. Melalui kegiatan saling berbagi cerita dan perasaan yang mereka alami membuat anggota kelompok belajar bahwa mereka tidak sendirian sehingga dapat saling membantu satu sama lain untuk mengatasi perasaan frustrasi, kesepian, dan putus asa (Xu \& Filler,2008). 
Pemberian Terapi Suportif terhadap keluarga diharapkan adanya peningkatan kemampuan keluarga dalam mengelola beban dan kecemasan dimana keluarga dapat kesempatan membahas masalah yang dihadapi dan dapat bertukar pengalaman dengan keluarga yang lain. Bertukar pengalaman dalam mengelola beban dan kecemasan selama merawat anak selama hospitalisasi dapat menjadi sumber dukungan sosial bagi masing-masing anggota dalam kelompok, sehingga diharapkan beban serta kecemasan dapat berkurang. Pemberian dukungan sosial dapat diberikan oleh anggota keluarga lainnya ataupun melalui bantuan tenaga professional, misalnya dengan seorang perawat professional atau perawat jiwa sebagai terapis (Videbeck, 2008).

Pemberian Terapi Suportif keluarga dapat meningkatkan kemampuan keluarga dalam mengelola kecemasan, dimana keluarga dapat membahas masalah yang dihadapi selama anak menjalani perawatan, sehingga memperoleh dukungan dari anggota keluarga lainnya dalam mengatasi kecemasannya. Berdasarkan hasil penelitian yang sudah dilakukan peneliti, bahwa pemberian Terapi Suportif dapat menurunkan kecemasan responden dengan penurunan skor kecemasan sebesar $48.37 \%$.

Hal ini membuktikan bahwa pemberian Terapi Suportif dapat digunakan untuk menurunkan tingkat kecemasan orangtua anak yang menjalani hospitalisasi, karena dengan pemberian Terapi Suportif dapat meningkatkan kekuatan bagi responden dalam menghadapi masalah anak yang menjalani hospitalisasi, mempunyai ketrampilan koping, serta kemampuan responden menggunakan sumber kopingnya.

\section{Perbedaan Pengaruh Terapi Relaksasi} Otot Progresif dan Terapi Suportif Terhadap Kecemasan orangtua dengan anak hospitalisasi

Hasil penelitian yang telah dilakukan oleh peneliti menunjukkan bahwa orangtua sebagai responden dengan anak yang menjalani hospitalisasi, mengalami kecemasan dan merasakan banyak keluhan fisik seperti ketegangan otot, merasa pusing, nyeri/sakit anggota badan, susah tidur, tidak dapat tidur nyenyak, masalah emosi seperti mudah marah, kurang sabar, pikiran tidak tenang, perasaan sedih, gelisah, kurangnya kemampuan berfikir. Setelah diberikan Terapi Relaksasi Otot Progresif sebagian besar dari keluhan fisik, psikologis dan emosi responden dapat teratasi, dan menunjukkan perubahan terhadap kecemasan.

Masalah ini sesuai dengan beberapa poin pertanyaan pada kuisioner kecemasan yang digunakan sebagai alat penelitian oleh peneliti menggunakan Hamilton Anxiety Rating Scale/HARS. Pemberian Terapi Relaksasi Otot Progresif mempunyai dampak secara langsung terhadap tanda dan gejala fisik dan psikologis yang diakibatkan oleh kecemasan, sehingga terjadi penurunan pada kecemasan responden. Hasil dari penelitian ini membuktikan bahwa Pemberian Terapi Relaksasi Otot Progresif sangat membantu masalah kecemasan dan masalah gangguan fisik serta psikologis yang dihadapi orangtua pada saat anak menjalani hospitalisasi.

Sedangkan Terapi Suportif merupakan salah satu bentuk psikoterapi yang dapat digunakan sebagai terapi kelompok untuk meningkatkan kemampuan keluarga/caregiver menggunakan sistem pendukung dalam mengatasi maasalah 
psikososial stress, kecemasan sebagai dampak merawat anak yang menjalani perawatan. Seorang individu dapat merasakan kehadiran teman atau significant other mampu menciptakan adanya perasaan cinta, prilaku dan adanya nilai caring, serta memberikan dukungan, sehingga individu akan dapat merasakan manfaat langsung dari pemberian praktek dukungan secara kelompok (Norbeck, 1981; Tsai \& Wang, 2009).

Sesuai dengan tujuan dari pelaksanaan Terapi Suportif agar terbentuknya hubungan terapeutik yang bermanfaat untuk meningkatkan ke-kuatan bagi klien, ketrampilan koping, serta kemampuan klien menggunakan sumber kopingnya, meningkatkan otonomi dalam pengambilan keputusan, meningkatkan kemampuan klien mencapai kemandirian yang lebih optimal, serta kemampuan mengurangi distress subyektif dan respon koping yang maladaptif dan koping merupakan salah satu usaha yang dapat dilakukan individu dalam mengatasi stress yang dihadapi (Stuart \& Laraia, 2008; Stuart,2009)

\section{SIMPULAN}

Hasil penelitian menyimpulkan bahwa terdapat penurunan skor kecemasan orangtua dengan anak hospitalisasi sebesar $68.87 \%$ sesudah diberikan Terapi Relaksasi Otot Pro-gresif, dan penurunan skor kecemasan orangtua dengan anak hospitalisasi sebesar $48.37 \%$ sesudah diberikan Terapi Suportif. Terapi Relaksasi Otot Progresif mempunyai pengaruh lebih besar dalam menurunkan kecemasan orangtua dengan anak hospitalisasi dibandingkan Terapi Suportif.

Perlu dikembangkan penelitian selanjutnya menggunakan modifikasi dari Terapi Relaksasi Otot Progresif dibandingkan Terapi Suportif pada kelompok lain, karena Terapi Relaksasi Otot Progresif selain. Perlu dikembangkan penelitian selanjutnya menggunakan Terapi Relaksasi Otot Progresif secara kelompok untuk menurunkan kecemasan pada kasus kecemasan lainnya. Perlu dikembangkan penelitian selanjutnya menggunakan modifikasi Terapi Relaksasi Otot Progresif dengan psikoterapi lain dalam mening-katkan intervensi keperawatan.

Fasilitas pelayanan kesehatan khususnya Rumah Sakit Umum perlu meningkatkan intervensi keperawatannya dengan memberikan pelayanan langsung tidak hanya terhadap pasien, tetapi juga memperhatikan pelayanan intervensi keperawatan terhadap orang tua/caregivers dengan menggunakan terapi spesialis seperti penerapan Terapi Relaksasi Otot Progresif dan Terapi Suportif, melalui tenaga keperawatan yang berkompeten. Perlu meningkatkan kualitas pelayanannya dengan peningkatan kompetensi perawat, sehingga dapat meningkatkan kemam-puan dalam memberikan implementasi keperawatan, dan dapat menunjang mutu dan kualitas pelayanan di masyarakat pada umumnya.

\section{DAFTAR PUSTAKA}

Audina M (2017) Hubungan dampak Hospitalisasi anak dengan tingkat
Kecemasan Orang Tua di IRNA E Atas RSUP Prof. Dr. R.D. Kandau Manado Apriany, D (2013) Hubungan antara 
hospitalisasi anak dengan tingkat kecemasan Orang tua di RSUD Kelas B Cianjur.

Choi,YK (2010) The Effect of Music and Progressive muscle Relaxation on Anxiety, Fatigue, and Quality of Life in Family Caregivers of Hospice Patients. http// doi. org/10.1093/jmt/47.1.53

Center for Clinical Intervention (2008) Progrssive Muscle Relaxation.http:// www.cci. health. wa.gov.a

Dewi E.I (2011) Pengaruh terapi kelompok Suportif Terhadap Beban dan Tingkat Ansietas Keluarga dalam Merawat Anak Tunagrahita di Sekolah Luar Biasa (SLB) Kabupaten Banyumas

Damayanti, R (2010) Pengaruh Terapi Suportif Keluarga Terhadap Ke-mampuan Keluarga Merawat Klien Gangguan Jiwa di Keca-matan Bogor Timur

Fatimah,U (2013) Pengaruh Pemberian Terapi Relaksasi Otot Progresif Terhadap Penurunan Tingkat Ke-cemasan pada Pasien Gagal Ginjal Kronik yang Menjalani Hemodialisa di RS.PKU Muha-mmadiyah Yogyakarta

Hidayat,A.A.A (2007) Metode Penelitian Keperawatan dan Teknik Analisa Data. Jakarta; Salemba Medika

Kavin,D (2011).Parental Involvement in the Treatment of Childhood Anxiety. Insights into Clinical Counselling

Kumayah. (2011) Kecemasan Orang Tua tentang Hospitalisasi pada Anak. Jurnal Kepe-rawatan.

Kurniawati,Id (2011) Hubungan Peran Keluarga terhadap Hospitalisasi pada Anak Toddler di ruang Melati RS.Mekar
Sari Bekasi

Lee, A \& Hankin.B (2009) insecure Attachment, Dysfungtional Attitude, and Low self Esteem Pre-dicting Prospective Symptoms of Depression and Anxiety during Adolescence. Jounals of Clinical Child and Adolescence Psychology, 38 (2): $219-231$

Notoatmojo (2010) Metodologi Penelitian Kesehatan, Jakarta: Rineka Cipta

Riset Kesehatan Dasar/RISKESDAS (2013) Jakarta: Riskesdas, 2013.

Ramdhani, N,\& Putra, A.A. (2008). Pengembangan multi media relaksasi. Laporan Penelitian.Yogyakarta: Fakultas Psikologi UGM.

Sugihartiningsih (2016) Gambaran Tingkat Kecemasan orangtua terhadap hospitalisasi anak di RSUD. Dr. Moewardi Saputri, F..D (2016) Pengaruh Rlaksasi Otot Progresif Terhadap Tingkat Kecemasan Ibu Primi Gravida Trimester.III di Puskesmas Sewon I Bantul

Sugiyono (2015) Metode Penelitian Manajemen, CV.Alfabeta

Sari, A.D.K (2015) pelatihan Teknik Relaksasi untuk Menurunkan Kecemasan pada Primary Caregiver pada Penderita Kanker Payudara

Suryanti, M. (2013).Pengaruh Terapi Ber-main Puzzle Terhadap Dampak Hospitalisasi pada Anak Usia Pra Sekolah di Ruang Anggrek.I Rumah Sakit Polpus R.S. Sukanto. Jakarata: Fakultas Kedokteran UPN Veteran Jakarta

Stuart.G.W (2013) Principles and Practice of Psychiatric nursing (10 th ed) St.Louis. Missouri: Mosby Elsevier Inc. 
Saedi,M. (2012) The Effect of Progressive Muscle Relaxation on Sleep Quality of Patients under going Hemodialysis

Sadock, B.J,\& Sadock, V.A (2010) Buku Ajar psikiatri klinis: Kaplan dan Sadock $\left(2^{\text {nd }}\right.$ ed.). Jakarta:EGC.

Sari,H (2010) Penerapan Terapi Kelompok Suportif pada Ibu Hamil dengan Ansietas melalui Pendekatan Teori Mercer di Kelurahan Balumbang Jaya Bogor Barat

Sugiyono (2010) Statistika untuk Penelitian. CV.Alfabeta

Supriatin,L (2010) Pengaruh terrapy Tought Stoping dan Progresive Muscle relaxation terhadap anisetas pada klien dengan gangguan fisik di RSUD. Dr. Soedono Madiun. Tesis tidak dipublikasikan.

Soewondo,S. (2009). Panduan dan in-struksi latihan relaksasi progresif. Depok: Lembaga pengembangan sarana pengukuran dan pendidikan psikologi.

Stuart, G.W (2009) Principles and Practice of Psychiatric nursing ( $9^{\text {th }}$ ed) St.Louis. Mosby

Stuart, G.W (2007) Principles and Practice of Psychiatric Nursing St.Louis, Missouri: Mosby Elsevier Inc.

Triwijaya, wagiyo dan Elisa (2014) Pengaruh Relaksasi Otot Progresif terhadap Penurunan Tingkat Kecemasan pada ibu intranatal Kala.I di RSUD Salatiga

Tobing D.L (2012) Pengaruh Progressive Muscle Relaxation dan Logoterapi terhadap Perubahan Ansietas, Depresi, Kemampuan Relaksasi dan Kemampuan
Memaknai Hidup Klien kanker di RS.Dharmais Jakarta.

Townsend,C.M (2009) Psychiatric Mental Health Nursing ( $\left.6^{\text {th }} . e d\right)$. Philadhelpia: Davis Company.

Tsai \& Wang (2009) The Relationship between Caregivers Strain an Social Support among Mothers with Intellectually Disabled children. Journal of Clinical Nursing.18, 539-548

Uskenat,M.D (2012) Perbedaan Tingkat Kecemasan pada Pasien Pre Operasi dengan General Anestesi Sebelum dan Sesudah diberikan Relaksasi Otot Progresif di RS. Panti Wilasa Citarum Semarang.

Unicef. (2013) United Nations Chil-dren's Fund.http://www.unicef.org/dprk/uniceffactsheet2013,

Videbeck,S.L (2008) Psychiatric Mental Health Nursing (4th ed) Philadelpia:Lippincott Williams \& Wilkins

Wahyuningsih, S.A (2011) Pengaruh terapi Suportif terhadap Kemampuan Keluarga Merawat Klien Gagal Ginjal Kronik (GGK) yang Men-jalani Hemodialisa di Rumah Sakit PELNI Jakarta.

Wahyuningsih, P (2008) Tingkat Kecemasan Orang Tua Terhadap Anak Yang Mengalami Hospi-talisasi di Ruang Mawar RSI Gondanglegi Malang. (http://www. keaslianpenelitian.go.id/download)

Xu, Y., \& Filler, J. (2008). Facilitating family involvement and support for inclusive education. The School Community Journal, 18(2), 53-7 